Jurnal Keperawatan Silampari

Volume 5, Nomor 1, Desember 2021

e-ISSN: 2581-1975

p-ISSN: 2597-7482

DOI: https://doi.org/10.31539/jks.v5i1.2965

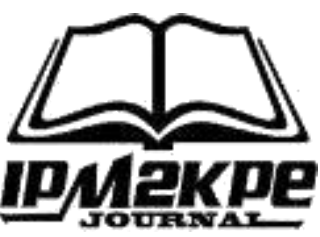

\title{
BUTEYKO BREATHING TECHNIQUE (BBT) TERHADAP PERUBAHAN NILAI PEAK EXPIRATORY FLOW RATE (PEFR) DAN KUALITAS HIDUP PENDERITA ASMA
}

\author{
Fransiska Kurniati Natul ${ }^{1}$, Sri Yona ${ }^{2}$ \\ Universitas Indonesia ${ }^{1,2}$ \\ fransiskanatul@gmail.com ${ }^{1}$
}

\begin{abstract}
ABSTRAK
Penelitian ini untuk bertujuan untuk mengetahui pengaruh teknik pernapasan buteyko terhadap perubahan laju aliran ekspirasi puncak dan kualitas hidup penderita asma. Metode yang digunakan dalam penelitian ini adalah pencarian literatur menggunakan database online seperti Pubmed/Medline, Proquest, Science Direct, dan EBSCO. Hasil penelitian menunjukan bahwa dari sepuluh studi percobaan Buteyko Breathing Technique (BBT) yang ditelaah, BBT secara signifikan mempengaruhi laju aliran puncak ekspirasi/ Peak Expiratory Flow Rate (PEFR) dan kualitas hidup pada penderita asma dewasa. Simpulan, teknik pernapasan buteyko terbukti cukup efektif dalam meningkatkan nilai PEFR dan kualitas hidup pada penderita asma, tanpa adanya temuan efek samping pada subyek yang diteliti.
\end{abstract}

Kata Kunci: Asma, Buteyko Breathing Technique (BBT), Kualitas Hidup, Laju Ekspirasi Puncak, Peak Expiratory Flow Rate (PEFR)

\section{ABSTRACT}

This study aimed to determine the effect of Buteyko's breathing technique on changes in peak expiratory flow rate and quality of life of asthmatics. The method used in this research is literature search using online databases such as Pubmed/Medline, Proquest, Science Direct, and EBSCO. The results showed that from ten experimental studies of the Buteyko Breathing Technique, BBT significantly affected peak expiratory flow rate (PEFR) and quality of life in adult asthmatics. In conclusion, the Buteyko breathing technique proved to be quite effective in increasing the PEFR value and quality of life in asthmatics, without any side effects in the subjects studied.

Keywords: Asthma, Buteyko Breathing Technique (BBT), Quality of Life, Peak Expiratory Rate, Peak Expiratory Flow Rate (PEFR)

\section{PENDAHULUAN}

Asma merupakan suatu penyakit heterogen yang menyerang individu dari segala usia (Ilmarinen et al., 2021). Menurut Global Initiative for Asthma GINA (2021), menjelaskan bahwa asma adalah suatu penyakit heterogen, yang biasanya ditandai dengan adanya peradangan pada saluran napas kronis. Hal ini ditentukan oleh riwayat gejala pernapasan seperti mengi, sesak napas, dada sesak dan batuk yang sangat lama dan dalam intensitas, bersama dengan kondisi keterbatasan aliran udara ekspirasi yang bervariasi. Penyakit asma mempengaruhi sekitar 300 juta orang di seluruh dunia dan 
sekitar 7,5\% orang dewasa di Amerika Serikat. Penyakit asma juga mempengaruhi sekitar $1 \%$ sampai $18 \%$ dari populasi di seluruh dunia. Setiap tahun, jumlah kematian akibat asma sekitar 180.000 dengan variasi yang luas antara usia, kelompok ekonomi, benua dan wilayah (GINA 2018; WHO 2018).

Di Indonesia prevalensi kejadian asma pada penduduk semua umur sebesar 2,4\% (Riskesdas, 2018). Asma ditandai dengan peradangan saluran udara, obstruksi aliran udara, dan hiperresponsif bronkus (Nanda \& Wasan, 2020). Sedangkan, berdasarkan data dari WHO (2021) menunjukan bahwa asma mempengaruhi sekitar 262 juta orang pada tahun 2019 dan menyebabkan 461000 kematian. Eksaserbasi bisa berakibat fatal dan lebih sering serta lebih serius pada pasien berisiko tinggi atau pasien dengan asma yang tidak terkontrol (GINA, 2018). Faktor-faktor seperti infeksi virus, alergen, asap tembakau, latihan fisik, stres, obat-obatan tertentu (obat antiinflamasi nonsteroid dan beta-blocker) dapat memicu atau memperburuk gejala asma (GINA 2018; WHO 2018). Beberapa fenotipe sudah teridentifikasi, seperti asma alergi, asma non-alergi, dan asma onset lambat (GINA ,2018).

Asma merupakan masalah kesehatan masyarakat yang serius yang merupakan penyebab utama kecacatan dan pemanfaatan sumber daya kesehatan bagi mereka yang terkena dampak, yang mungkin memerlukan perawatan darurat (Nunes et al., 2017). Walaupun tidak ada obat untuk asma yang diketahui, ada berbagai intervensi farmakologis dan non-farmakologis yang dapat membantu orang mengontrol gejala pada pasien asma (GINA 2018). Intervensi non-farmakologis rupanya telah mendapat perhatian dalam pengobatan asma. Intervensi tersebut termasuk latihan pernapasan, aktivitas fisik, dan strategi lain seperti berhenti merokok, menghindari paparan pekerjaan dan alergen dalam ruangan, dan penurunan berat badan, dan lain-lain (GINA, 2018). Hampir $6 \%$ sampai $30 \%$ pasien asma dilaporkan menggunakan berbagai metode pernapasan untuk membantu mengendalikan gejala mereka untuk meminimalkan ketergantungan mereka pada obat-obatan (Hall et al., 2017).

Penyakit asma perlu penanganan yang baik dari tenaga kesehatan karena penyakit tersebut bisa dialami terus menerus oleh anak bahkan sampai dewasa. Oleh karena itu perlu adanya terapi yang dapat diberikan, baik terapi farmakologis maupun terapi non farmakologis. Terapi non farmakologis yang bisa diberirikan pada anak adalah teknik pernapasan (Harsismanto et al., 2021).

Adapun beberapa teknik pernapasan telah disarankan untuk membantu mengontrol asma, tetapi memiliki teknik dan mekanisme yang berbeda secara substansial. Breating exercise merupakan intervensi multi-komponen yang bertujuan untuk mengubah perilaku dan melibatkan berbagai metode dan teknik latihan pernapasan seperti metode buteyko, pernapasan yoga, metode papworth, dan pernapasan diafragma (Bailey et al., 2016). Teknik pernapasan buteyko bertujuan untuk meningkatkan kesadaran pernapasan secara umum dan untuk menormalkan ventilasi dengan mengurangi volume tidal dan laju pernapasan (Campbell et al., 2018).

Asma yang tidak terkontrol merupakan tantangan kesehatan global dengan dampak besar pada kualitas hidup (QoL) dan biaya perawatan kesehatan secara keseluruhan. Komorbiditas yang tidak dikenali dan/atau tidak terkelola sering berkontribusi terhadap adanya asma yang tidak terkontrol. Kelainan pada pola pernapasan disebut pernapasan disfungsional dan tidak hanya umum pada gejala asma tetapi juga berdampak pada penurunan kualitas hidup penderita asma (Harsismanto et al., 2021; Karen et al., 2019). 
Didukung oleh penelitian yang dilakukan oleh Sutrisna et al., (2018) menunjukan bahwa BBT berpengaruh terhadap Asthma Control Test (ACT). Adapun juga hasil penelitian dari Wijaya et al., (2020) menunjukan bahwa pemberian teknik pernafasan buteyko dapat meningkatkan laju puncak ekspirasi atau Peak Expiratory Flow Rate (PEFR) pada pasien asma, dimana sebelum pemberian teknik BBT skor PEFR sebesar $75,764 \%$ dan setelah diberikan teknik BBT mengalami peningkatan sebsar 79, 986\%. PEFR merupakan salah satu indikator umum gejala terkait asma. PEFR digunakan untuk menginterpretasikan tingkat keparahan atau eksaserbasi pada populasi penderita asma yang seringkali menggunakan peak flow meter sebagai alat ukurnya (Bae et al., 2021). Menurunnya PEFR disebabkan oleh proses ekspirasi yang menyebabkan terjadainya kontraksi otot pernapasan minimal, sehingga diafragma terdorong ke bawah dan karbondioksida yang keluar dari paru-paru sedikit. Selain meningkatkan laju puncak ekspirasi, Hall et al., (2017) mengatakan bahwa ada beberapa percobaan yang mengatakan teknik BBT dapat meningkatkan kualitas hidup pada pasien asma.

Kualitas hidup terkait asma menggambarkan gangguan subjektif yang diberikan oleh asma pada kehidupan seseorang (Karen, et al, 2019). Penelitian yang dilakukan oleh (Fard et al., 2016), menunjukan bahwa terdapat 46,8\% penderita asma melaporkan kualitas hidup yang tidak diinginkan dan hanya $26 \%$ pasien yang mengatakan bahwa mereka memiliki kualitas hidup yang diinginkan. Quality of Life (QoL) pasien asma, yang dikenal sebagai alat evaluasi klinis, mencerminkan dampak penyakit pada kehidupan pasien. Kerena penyakit asma merupakan masalah kesehatan kronis yang biasanya meliputi seumur hidup pasien dan dapat mengakibatkan keterbatasan fisik, emosional, dan sosial bagi pasien itu sendiri. Penatalaksanaan asma yang rasional mengarah pada pengendalian penyakit dan kualitas hidup yang lebih baik. Oleh karena itu, sangat penting untuk mengevaluasi kualitas hidup pasien selain gejala untuk menilai manajemen asma sepenuhnya (Agarwal et al., 2017).

Namun, sejauh ini belum diketahui secara rinci terkait penatalaksanaan nonfarmakologi yang dapat membantu meningkatkan fungsi paru dalam hal ini PEFR yang berdampak pada peningkatan kualitas hidup penderita asma. Penting diketahui bahwa manajemen asma tidak hanya berpusat pada pengobatan secara farmakologi saja, akan tetapi tindakan non-farmakologi juga yakni dengan menggunakan breathing exercise dapat meminimalakan efek samping pengobatan pada pasien asma. Hal inilah yang mendasari peneliti melakukan telaah sistematik terhadap pengaruh buteyko breathing technique pada perubahan nilai PEFR dan kualitas hidup penderita asma.

\section{METODE PENELITIAN}

Penulisan artikel ini dilakukan dengan menggunakan penelusuran literature secara sistematik menggunakan PICO. Pencarian artikel dengan pertanyaan klinis "Bagaimanakah pengaruh Buteyko Breathing Technique terhadap Perubahan Nilai PEFR dan kualitas Hidup Penderita Asma?". Pencarian literature menggunakan database online seperti ScienceDirect, Proquest, Pubmed/Medline, dan EBSCO. Kata kunci pencarian yang digunakan adalah Asthma AND Buteyko Breathing Technique OR Buteyko Breathing Methode OR Breathing exercise AND Peak Experiatory Flow Rate (PEFR) AND Quality of Life (QOL)baik sebagai teks bebas dan menggunakan istilah Medical Subject Headings (MESH).

Adapun filter pencarian yang digunakan oleh penulis sesuai dengan kriteria inklusi yang telah ditetapkan yakni artikel penelitian (original research), membahasa tentang buteyko breathing terhadap pasien asma dewasa usia 17-80 tahun, jurnal yang 
digunakan tahun terbit 2017-2021 dan berbahasa inggris. Kriteria ekslusinya yakni artikel yang tidak dapat diakses secara full text, pasien anak-anak dan artikel systematic review.
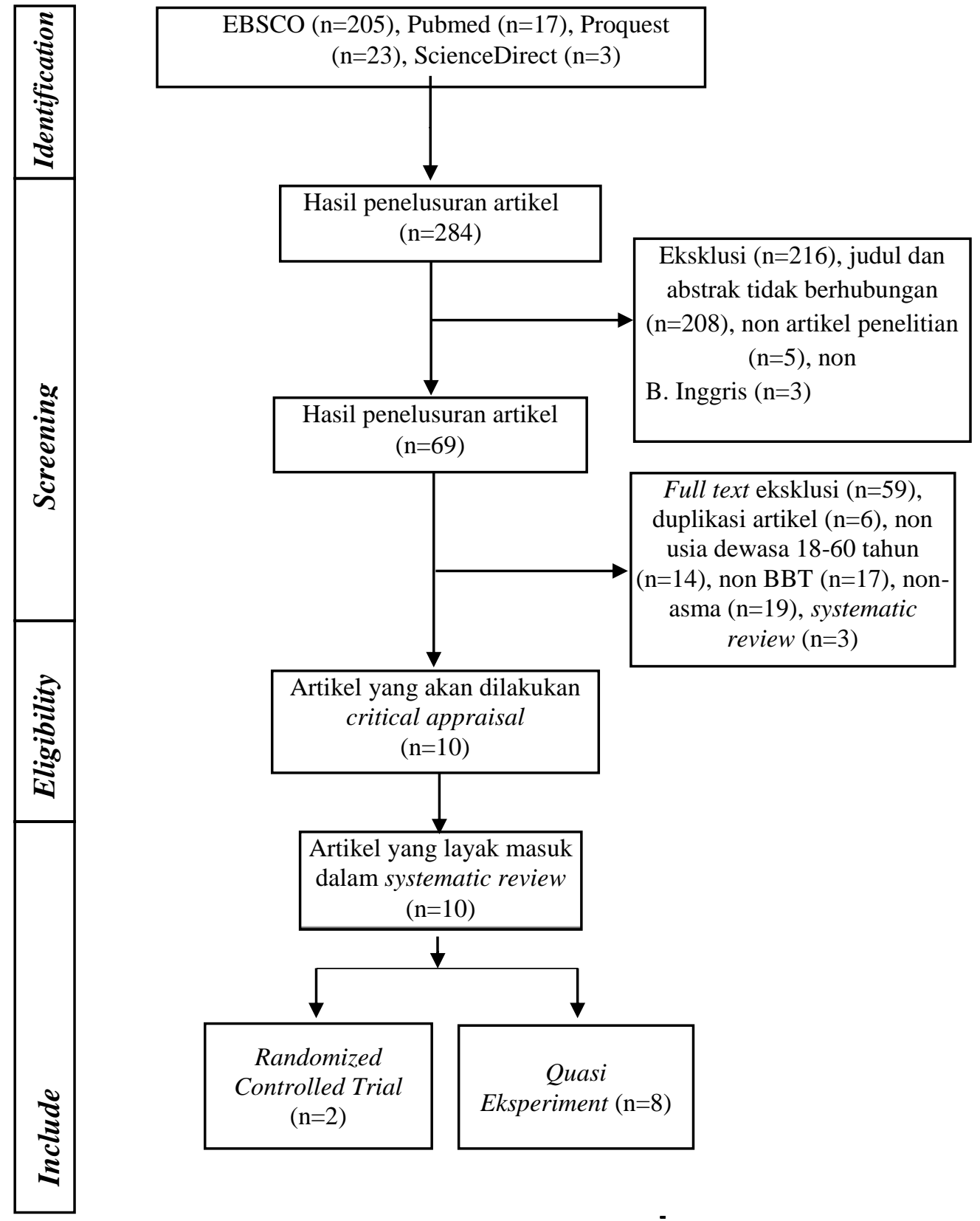

Gambar. 1

Skema Penelitian

\section{HASIL PENELITIAN}

Jumlah artikel yang digunakan dalam tinjauan sistematik ini sebanyak 10 artikel. Artikel yang ditelaah memiliki desain quasi eksperiment (delapan artikel) dan randomized controlled trial (dua artikel). Hasil telaah kritik artikel yang digunakan adalah sebanyak 2.556 orang terdiri dari para penderita asma. Pada analisis ditemukan tema utama yakni pengaruh teknik pernapasan buteyko terhadap perubahan nilai PEFR kualitas hidup penderita asma. 
Tabel. 1

Hasil Telaah Artikel

\begin{tabular}{|c|c|c|c|}
\hline $\begin{array}{l}\text { Pengarang, Judul, Jenis } \\
\text { Literatur }\end{array}$ & Tahun & Tujuan & Hasil Temuan \\
\hline $\begin{array}{l}\text { Karpagam et al., } \\
\text { Effectiveness of Buteyko } \\
\text { Breathing Technique and } \\
\text { Pursed Lip Breathing } \\
\text { Technique in Improving Peak } \\
\text { Expiratory Flow Rate in } \\
\text { Patients With Asthma, } \\
\text { Quasy Experiment }\end{array}$ & 2017 & $\begin{array}{l}\text { Untuk mengetahui } \\
\text { Efektivitas Teknik } \\
\text { Pernapasan Buteyko } \\
\text { dan Teknik } \\
\text { Pernapasan Bibir } \\
\text { Pursed dalam } \\
\text { Meningkatkan Laju } \\
\text { Aliran Ekspirasi } \\
\text { Puncak Pada } \\
\text { Penderita Asma }\end{array}$ & $\begin{array}{l}\text { Pengaruh Buteyko } \\
\text { Breathing Technique } \\
\text { terhadap Penderita } \\
\text { asma: Peningkatan nilai } \\
\text { PEFR Pengurangan } \\
\text { gejala asma setalah } \\
\text { diberikan BBT }\end{array}$ \\
\hline $\begin{array}{l}\text { Mohamed et al., } \\
\text { Buteyko Breathing Technique: } \\
\text { A Golden Cure for Asthma, } \\
\text { Quasy Experiment }\end{array}$ & 2018 & $\begin{array}{l}\text { Untuk mengevaluasi } \\
\text { pengaruh teknik } \\
\text { pernapasan Buteyko } \\
\text { pada pasien dengan } \\
\text { asma bronkial }\end{array}$ & $\begin{array}{l}\text { Pengaruh Buteyko } \\
\text { Breathing Technique } \\
\text { terhadap Penderita } \\
\text { asma: Tingkat } \\
\text { keparahan asma } \\
\text { berkurang } \\
\text { Peningkatan aliran } \\
\text { ekspirasi puncak } \\
\text { (PEFR) Control asma } \\
\text { meningkat }\end{array}$ \\
\hline $\begin{array}{l}\text { Arora \& Subramanian, } \\
\text { To Study the Effect of } \\
\text { Buteyko Breathing Technique } \\
\text { in Patients with Obstructive } \\
\text { Airway Disease, } \\
\text { Quasy Experimet }\end{array}$ & 2019 & $\begin{array}{l}\text { Membandingkan } \\
\text { efektivitas teknik } \\
\text { pernapasan buteyko } \\
\text { dan pernapasan } \\
\text { bibir mengerut pada } \\
\text { penyakit paru } \\
\text { obstruktif kronik } \\
\text { yang lebih baik }\end{array}$ & $\begin{array}{l}\text { Pengaruh Buteyko } \\
\text { Breathing Technique } \\
\text { terhadap Penderita } \\
\text { asma: Peningkatan } \\
\text { control pernapasan } \\
\text { Pengurangan kerja } \\
\text { pernapasan }\end{array}$ \\
\hline $\begin{array}{l}\text { El-Nahas et al., } \\
\text { Effect of Buteyko Breathing } \\
\text { on Modulation of Acid Base } \\
\text { Balance Among Asthmatic } \\
\text { Patients, } \\
\text { Randomized Controlled Trial }\end{array}$ & 2019 & $\begin{array}{l}\text { Untuk mengetahui } \\
\text { pengaruh teknik } \\
\text { pernapasan Buteyko } \\
\text { (BBT) sebagai } \\
\text { pengobatan } \\
\text { tambahan pada gas } \\
\text { darah pada pasien } \\
\text { asma }\end{array}$ & $\begin{array}{l}\text { Pengaruh Buteyko } \\
\text { Breathing Technique } \\
\text { terhadap Penderita } \\
\text { asma: BBT memiliki } \\
\text { efek termodulasi pada } \\
\text { arterial blood gases } \\
\text { (ABG) Pengurangan } \\
\text { kekambuhan serangan } \\
\text { asma Pengurangan } \\
\text { keparahan gejala asma }\end{array}$ \\
\hline $\begin{array}{l}\text { Mohamed et al., } \\
\text { The Effect of Buteyko } \\
\text { Breathing Technique among } \\
\text { Patients with Bronchial } \\
\text { Asthma: Comparative Study, } \\
\text { Quasy Experiment }\end{array}$ & 2019 & $\begin{array}{l}\text { Untuk menilai } \\
\text { pengaruh berlatih } \\
\text { teknik pernapasan } \\
\text { Buteyko pada gejala } \\
\text { asma di antara } \\
\text { pasien dengan asma } \\
\text { bronkial. }\end{array}$ & $\begin{array}{l}\text { Pengaruh Buteyko } \\
\text { Breathing Technique } \\
\text { terhadap Penderita } \\
\text { asma: Tingkat } \\
\text { keparahan gejala yang } \\
\text { membutuhkan } \\
\text { pengobatan berkurang, }\end{array}$ \\
\hline $\begin{array}{l}\text { Huidrom et al., Effectiveness } \\
\text { Of Buteyko Breathing } \\
\text { Technique on Respiratory } \\
\text { Physiological Parameters } \\
\text { Among Patients with } \\
\text { Bronchial Asthma, } \\
\text { Quasy Experiment }\end{array}$ & 2019 & $\begin{array}{l}\text { Untuk menilai } \\
\text { efektivitas teknik } \\
\text { pernapasan buteyko } \\
\text { pada parameter } \\
\text { fisiologis } \\
\text { pernapasan }\end{array}$ & $\begin{array}{l}\text { Pengaruh Buteyko } \\
\text { Breathing Technique } \\
\text { terhadap Penderita } \\
\text { asma:cPeningkatkan } \\
\text { parameter fisiologis } \\
\text { pernapasan di antara } \\
\text { pasien dengan asma } \\
\text { bronkial. }\end{array}$ \\
\hline
\end{tabular}




\begin{tabular}{|c|c|c|c|}
\hline $\begin{array}{l}\text { Kamalam et al., } \\
\text { An Analysis on the Effect of } \\
\text { Buteyko Breathing and } \\
\text { Relaxed Postures Over the } \\
\text { Chest Exapnsion of Asthmatic } \\
\text { Collegiate Population- An } \\
\text { Experimental Study, } \\
\text { Quasi Experiment }\end{array}$ & 2019 & $\begin{array}{l}\text { Untuk } \\
\text { mengidentifikasi } \\
\text { kemungkinan faktor } \\
\text { potensial untuk } \\
\text { meningkatkan } \\
\text { ekspansi dada } \\
\text { dengan } \\
\text { menganalisis efek } \\
\text { pernapasan buteyko } \\
\text { dan postur santai }\end{array}$ & $\begin{array}{l}\text { Pengaruh Buteyko } \\
\text { Breathing Technique } \\
\text { terhadap Penderita } \\
\text { asma: } \\
\text { BBT mempengaruhi } \\
\text { peningkatan laju puncak } \\
\text { ekpirasi } \\
\text { BBT meningkatkan } \\
\text { kualitas hidup penderita } \\
\text { asma. }\end{array}$ \\
\hline $\begin{array}{l}\text { Rahi et al., } \\
\text { Effect of Buteyko Method on } \\
\text { Lungs Function among } \\
\text { Asthmatic Patients in Al-Najaf } \\
\text { City, } \\
\text { Quasy Experiment }\end{array}$ & 2019 & $\begin{array}{l}\text { Untuk mempelajari } \\
\text { dan mengetahui } \\
\text { pengaruh metode } \\
\text { Buteyko terhadap } \\
\text { fungsi paru pada } \\
\text { pasien asma di kota } \\
\text { Najaf al-Ashraf }\end{array}$ & $\begin{array}{l}\text { Pengaruh Buteyko } \\
\text { Breathing Technique } \\
\text { terhadap Penderita } \\
\text { asma: } \\
\text { Penerapan BBT dapat } \\
\text { memperbaiki paru-paru } \\
\text { pasien asma } \\
\text { BBT meningkatkan } \\
\text { kapasitas paru } \\
\text { BBT mengatasi } \\
\text { masalah yang dihadapi } \\
\text { selama serangan asma. }\end{array}$ \\
\hline $\begin{array}{l}\text { Jagtap \& Vardan, } \\
\text { Effect of Buteyko Breathing } \\
\text { Technique on Peak Expiratory } \\
\text { Flow Rate in Bronchial } \\
\text { Asthma, Quasy Experiment }\end{array}$ & 2020 & $\begin{array}{l}\text { Untuk menilai } \\
\text { pengaruh DDT } \\
\text { terhadap Peak } \\
\text { Expiratory Flow } \\
\text { Rate (PEFR) pada } \\
\text { asma bronkial }\end{array}$ & $\begin{array}{l}\text { Pengaruh Buteyko } \\
\text { Breathing Technique } \\
\text { terhadap Penderita } \\
\text { asma: } \\
\text { BBT memperbaiki } \\
\text { status pernafasan pada } \\
\text { pasien asma bronkial } \\
\text { BBT dapat mengurangi } \\
\text { kekambuhan dan } \\
\text { keparahan gejala asma } \\
\text { bronkial } \\
\text { BBT meningkatkan laju } \\
\text { aliran ekspirasi puncak } \\
\text { (PEFR) dalam jangka } \\
\text { waktu } 4 \text { minggu. }\end{array}$ \\
\hline $\begin{array}{l}\text { Ausaf et al., } \\
\text { Effects of Buteyko Breathing } \\
\text { Technique and Conventional } \\
\text { Physical Therapy in Adult } \\
\text { Bronchial Asthma: A } \\
\text { Randomized Control Trial, } \\
\text { Randomized Controlled Trial }\end{array}$ & 2020 & $\begin{array}{l}\text { Untuk menilai } \\
\text { efektivitas Teknik } \\
\text { Pernapasan Buteyko } \\
\text { (BBT) dan Terapi } \\
\text { Fisik Konvensional } \\
\text { (PT Konvensional) } \\
\text { untuk meningkatkan } \\
\text { fungsi paru dan } \\
\text { Health Related } \\
\text { Quality of Life } \\
\text { (HRQoL) dalam } \\
\text { pengelolaan asma } \\
\text { bronkial kronis }\end{array}$ & $\begin{array}{l}\text { Pengaruh Buteyko } \\
\text { Breathing Technique } \\
\text { terhadap Penderita } \\
\text { asma: } \\
\text { BBT dapat } \\
\text { meningkatkan kualitas } \\
\text { hidup pasien asma }\end{array}$ \\
\hline
\end{tabular}

Pengaruh Buteyko Breathing Technique (BBT) terhadap fungsi paru dan kualitas hidup penderita asma bersifat positif. Metode buteyko mencoba mengoptimalkan pernapasan untuk menormalkan volume dan laju pernapasan agar lebih sesuai dengan kebutuhan metabolisme untuk menghindari overbreathing (hiperventilasi kronis). Beberapa cara kerja BBT didapatkan mampu mengurangi ventilasi paru yang meningkatkan kadar 
karbon dioksida dalam tubuh yang dengan demikian, meningkatkan pengiriman oksigen ke jaringan dan sel. Pengaruh BBT memberi dampak yang sangat baik pada aliran puncak ekspirasi dan kualitas hidup pasien asma. Selain itu, BBT terbukti dapat mengurangi kekambuhan dan keparahan serangan asma, tingkat control asma meningkat, serta meningkatkan parameter fisiologis pernafasan.

\section{PEMBAHASAN}

Buteyko Breathing Technique (BBT) dianggap sebagai bagaian dari breathing exercise yang merupakan suatu terapi non farmakologi yang berdampak pada peningakatan fungsi paru dan kualitas hidup pasien asma. (Jagtap et al., 2020), mengatakan bahwa teknik pernapasan buteyko secara signifikan dapat mengurangi kekambuhan dan keparahan gejala asma bronkial serta meningkatkan laju aliran ekspirasi puncak dalam jangka waktu 4 minggu. Hal ini dibuktikan dengan hasil penelitian dengan rerata nilai Peak Expiratory Flow Rate (PEFR) sebelum pemberian BBT adalah 103 $\pm 33,888 \mathrm{~L} / \mathrm{min}$ dan setelah pemberian BBT mengalami peningakatan PEFR yakni 141,5 $\pm 49,3 \mathrm{~L} / \mathrm{min}$. Salah satu indikator umum gejala terkait asma adalah PEFR (Bae et al., 2021).

PEFR merupakan volume udara yang dikeluarkan secara paksa dari paru-paru dalam satu pernafasan cepat, dan merupakan indikator yang dapat diandalkan untuk kecukupan ventilasi serta obstruksi aliran udara (Gulla \& Kabra, 2017). Selanjutnya beberapa penelitian mengatakan bahwa pemberian BBT selain efektif dalam meningkatkan nilai laju puncak ekspirasi juga dapat memberikan manfaat yang menguntungkan dalam pengurangan gejala asma (Karpagam et al., 2017); Kamalam et al., 2019). Mengenai peningakatan laju puncak ekpirasi ini Mohamed et al., (2018) menyebutkan bahwa hal ini mungkin disebabkan oleh tindakan ilmiah teknik buteyko yang didasarkan pada peningkatan bronkospasme yang mengarah pada peningkatan kecepatan ekspirasi yang maksimal.

Pada umumnya praktik teknik buteyko ini didasarkan pada peningkatan kesadaran pasien tentang penurunan intensitas pernapasan dan penggunaan pernapasan dangkal (Ochiană \& Ochiana, 2017). Akibat dari penggunaan teknik pernapasan buteyko ini tentunya membawa pengaruh positif yang dirasakan manfaatnya oleh pasien asma seperti pengurangan kekambuhan serangan asma dan keparahan gejala asma (Jagtap et al 2020; Kamalam et al., 2019; Huidrom et al., 2019; Rahi et al., 2019; Mohamed at al., 2019; Mohamed et al., 2018; Karpagam et al., 2017). Hal ini didukung oleh Sutrisna \& Arfianti (2020) yang mengatakan bahwa ada beberapa kelebihan dari teknik pernapasan buteyko ini antara lain dapat menurunkan frekuensi serangan asma bronkial (meningkatkan kontrol asma, mencegah tingkat keparahan asma, menurunkan penggunaan dosis inhalasi kortikosteroid serta memperbaiki PEFR). Selain mempengaruhi peningkatan nilai laju puncak ekpirasi atau PEFR, teknik pernafasan buteyko cukup efektif dalam meningkatkan kualitas hidup penderita asma (Ausaf et al., 2020; Kamalam et al., 2019).

Asma yang tidak terkontrol merupakan tantangan kesehatan global dengan dampak besar pada kualitas hidup (QoL) dan biaya perawatan kesehatan secara keseluruhan. Komorbiditas yang tidak dikenali dan/atau tidak terkelola sering berkontribusi terhadap adanya asma yang tidak terkontrol. Kelainan pada pola pernapasan disebut pernapasan disfungsional dan tidak hanya umum pada gejala asma tetapi juga berdampak pada penurunan kualitas hidup penderita asma (Harsismanto et al., 2020; Karen et al., 2019).

Hasil temuan Arora \& Subramanian (2019) menyebutkan bahwa terdapat beberapa hal yang mendukung mengenai penerapan BBT pada pasien asma; 1) pengurangan hiperventilasi dan gejala utama pada asma bronkial seperti bronkospasme, batuk, ekspektorasi, hidung tersumbat; 2) penurunan jumlah serangan asma dan tingkat 
keparahannya serta mengurangi penggunaan obat-obatan; 3) metode BBT efisien pada periode asma akut, berkontribusi pada peningkatan kesehatan umum pasien dan pengendalian keadaan panik pasien; 4) BBT menawarkan pasien pendekatan efisien dan global untuk penyakit asma karena PPT dapat digunakan dimana saja, kapan saja, menawarkan kontrol alami atas terjadinya gejala asma bronkial tanpa menggunakan obatobatan, suplemen atau inhaler; 5) BBT adalah terapi alternatif yang menyarankan reteaching of breathing, sebagai pengobatan untuk asma serta untuk afeksi lainnya: keadaan panik, cephalgia, kecemasan, sleep apnea, insomnia dan dyspnea, gangguan paru obstruktif kronik, efisema paru. Selain itu temuan dari Kamalam et al, 2019 menyebutkan juga teknik pernapasan Buteyko bermanfaat dalam menormalkan pernafasan, meningkatkan kebugaran jasmani dan kualitas hidup, meningkatkan kepercayaan psikologis, mengurangi tingkat kecemasan aktifitas fisik, mengurangi gejala asma dan penggunaan obat inhaler, serta teknik BBT tidak memiliki efek samping.

\section{SIMPULAN}

Teknik pernapasan buteyko terbukti cukup efektif dalam meningkatkan nilai PEFR dan kualitas hidup pada penderita asma, tanpa adanya temuan efek samping pada subyek yang diteliti.

\section{SARAN}

Para peneliti menyarankan agar teknik pernapasan buteyko ini ditambahkan sebagai intervensi medis dan keperawatan dalam menajemen pasien asma. Namun, belum cukup bukti mengenai BBT dalam mengobati penyakit asma. Latihan pernapasan buteyko mungkin memiliki beberapa efek positif pada kualitas hidup, gejala hiperventilasi, dan fungsi paru-paru. Oleh karena itu, diperlukan penelitian lebih lanjut termasuk deskripsi lengkap tentang metode pengobatan terkait BBT.

\section{DAFTAR PUSTAKA}

Agarwal, D., Gupta, P., \& Sood, S. (2017). Assessment for Efficacy of Additional Breathing Exercises Over Improvement in Health Impairment Due to Asthma Assessed Using St. George's Respiratory Questionnaire. International Journal of Yoga, 10(3), 144. https://doi.org/10.4103/0973-6131.213472

Arora, R. D., \& Subramanian, V. H. (2019). To Study the Effect of Buteyko Breathing Technique in Patients with Obstructive Airway Disease. Original Research Article. https://www.ijhsr.org/IJHSR_Vol.9_Issue.3_March2019/8.pdf

Ausaf, Q. U. A., Nizami, G. N., \& Khan, A. A. (2020). Effects of Buteyko Breathing Technique and Conventional Physical Therapy in Adult Bronchial Asthma: A Randomized Control Trial. Pakistan Journal of Rehabilitation, 6(1), 36-44. Retrieved from http://ojs.zu.edu.pk/ojs/index.php/pjr/article/view/765

Bae, W. D., Kim, S., Park, C.-S., Alkobaisi, S., Lee, J., Seo, W., Park, J. S., Park, S., Lee, S., \& Lee, J. W. (2021). Performance Improvement of Machine Learning Techniques Predicting the Association of Exacerbation of Peak Expiratory Flow Ratio with Short Term Exposure Level to Indoor Air Quality Using Adult Asthmatics Clustered Data. PLOS ONE, 16(1). https://doi.org/10.1371/journal.pone.0244233

Bailey, N. W., Bridgman, T. K., Marx, W., \& Fitzgerald, P. B. (2016). Asthma and Mindfulness: an Increase in Mindfulness as the Mechanism of Action Behind Breathing Retraining Techniques? Mindfulness, 7(6). https://doi.org/10.1007/s12671016-0551-7 
Campbell, T. G., Hoffmann, T. C., \& Glasziou, P. P. (2018). Buteyko Breathing for Asthma. Cochrane Database of Systematic Reviews, 2018(8). https://doi.org/10.1002/14651858.CD009158.pub2

El-Nahas, N., El-Deen, H., Ahmed, K., Ghaly, L. (2019). Effect of Buteyko Breathing on Modulation of Acid Base Balance Among Asthmatic Patients. Bioscience Research. 16(1), 281-286. https://www.researchgate.net/publication/332014202

Fard, M. S., Miladinia, M., Khah, H. Z. H., Borsi, S. H., \& Zarea, K. (2016). Studying of the Status of Quality of Life And Its Predictors in Adult Asthmatic Patients in Ahvaz: Basic Information for Better Control of Asthma. Jundishapur Journal of Chronic Disease Care, 6(1), e38668. https://doi.org/10.17795/jjcdc-38668

Global Initative for Asthma (GINA). (2018). GINA Report, Global Strategy for Asthma Management and Prevention. Diakses dari https://ginasthma.org/wpcontent/uploads/2018/04/wms-GINA-2018-report-V1.3-002.pdf

Global Initative for Asthma (GINA). (2021). GINA Report, Global Strategy for Asthma Management and Prevention. Diakses dari https://ginasthma.org/wpcontent/uploads/2021/05/Whats-new-in-GINA-2021_final_V2.

Gulla, K. M., \& Kabra, S. K. (2017). Peak Expiratory Flow Rate as a Monitoring Tool in Asthma. The Indian Journal of Pediatrics, 84(8), 573-574. https://doi.org/10.1007/s12098-017-2398-x

Hall, C., Nici, L., Sood, S., ZuWallack, R., \& Castro, M. (2017). Nonpharmacologic Therapy for Severe Persistent Asthma. J Allegry Clin Immunol Pract, 5(4), 928-935. DOI: 10.1016/j.jaip.2017.04.030

Harsismanto, J., Padila, P., Andri, J., Andrianto, M, B., \& Sartika, A. (2021). Respiratory Frequency of Children with Asthma Using Superbubbles Blood Intervention. JOSING: Journal of Nursing and Health,2(1), 28-32. https://doi.org/https://doi.org/10.31539/josing.v2i1.3052

Harsismanto, J., Padila, P., Andri, J., Andrianto, M, B., \& Yanti, L. (2020). Frekuensi Pernafasan Anak Penderita Asma Menggunakan Intervensi Tiup Super Bubbles dan Meniup Baling Baling Bambu. Journal of Telenursing (JOTING), 2(2), 119-126. https://doi.org/https://doi.org/10.31539/joting.v2i2.1409

Huidrom, K., Shiroor, G., Ray, S. P. (2019). Effectiveness Of Buteyko Breathing Technique on Respiratory Physiological Parameters Among Patients with Bronchial Asthma. International Journal of Recent Scientific Research (IJRSR). 7. 1132811331. http://www.recentscientific.com

Hossny, E., Caraballo, L., Casale, T., El-Gamal, Y., \& Rosenwasser, L. (2017). Severe Asthma and Quality of Life. World Allergy Organization Journal, 10(1). https://doi.org/10.1186/s40413-017-0159-y

Ilmarinen, P., Stridsman, C., Bashir, M., Tuomisto, L. E., Vähätalo, I., Goksör, E., Kankaanranta, H., Backman, H., Langhammer, A., Piirilä, P., Rönmark, E., Lundbäck, B., Nwaru, B. I., \& Wennergren, G. (2021). Level of Education and Asthma Control in Adult-Onset Asthma. Journal of Asthma, 1-20. https://doi.org/10.1080/02770903.2021.1871742

Jagtap, R. N., Vardhan, V. D. G. (2012). Effect of Buteyko Breathing Technique on Peak Expiratory Flow Rate in Bronchial Asthma. International Journal of Scientific Research, 9(3), 51-52. https://www.worldwidejournals.com/international-journal-ofscientific-research-(IJSR) 
Kamalam, S., Srividya, G., Milton, J. (2019). An Analysis on the Effect of Buteyko Breathing and Relaxed Postures Over the Chest Exapnsion of Asthmatic Collegiate Population- An Experimental Study. International Journal Medical and Exercise Science. 05, 567-575. 10.36678/ijmaes. 2019. v05i02.002

Karen, H. A., Søren, T. S., Ulrik, C. S., Madsen, H., Sidenius, K., Jannie Søndergaard Jacobsen, \& Bodtger, U. (2019). Protocol for a Multicentre Randomised Controlled Trial to Investigate the Effect on Asthma-Related Quality of Life from Breathing Retraining in Patients with Incomplete Asthma Control Attending Specialist Care in Denmark. BMJ Open, 9(12). DOI:http ://dx.doi.org/10.1136/ bmjopen-2019-032984

Karpagam, K., Mangalagowri, P., \& Shanmugam, A. (2017). Effectiveness of Buteyko Breathing Technique and Pursed Lip Breathing Technique in Improving Peak Expiratory Flow Rate in Patients With Asthma. International Journal of Pharma and Bio Sciences, 8(3), 457-464. DOI:10.22376/ijpbs.2017.8.3.b457-464

Mohamed, E. M. H., ELmetwaly, A. A. M., \& Ibrahim, A. M. (2018). Buteyko Breathing Technique: A Golden Cure for Asthma. American Journal of Nursing Research, 6(6), 616-624. http://pubs.sciepub.com/ajnr/6/6/32

Mohamed, Y., Ibrahim, L., Elderiny, S. (2019). The Effect of Buteyko Breathing Technique among Patients with Bronchial Asthma: Comparative Study. International Journal of Midwifery and Nursing Practice., 2(2), 01-10. DOI: http://dx.doi.org/10.13140/RG.2.2.35603.20007

Nanda, A., \& Wasan, A. N. (2020). Asthma in Adults. Medical Clinics of North America, 104, (1), 95-108. https://doi.org/10.1016/j.mcna.2019.08.013

Nunes, C., Pereira, A. M., \& Morais-Almeida, M. (2017). Asthma Costs and Social Impact. Asthma Research and Practice, 3(1). https://doi.org/10.1186/s40733-016-0029-3

Ochiană, G., \& Ochiana, N. (2017). The Efficiency of the Buteyko Method in Improving the Functional Parameters in the Bronchial Asthma-Case Study. Gymnasium, 13(1), 2344-5645. http://www.gymnasium.ub.ro/index.php/journal/article/view/217

Rahi, A. A., Jaber, A. M., Ali-Abd, D. K. (2019). Effect of Buteyko Method on Lungs Function among Asthmatic Patients in Al-Najaf City. Kufa Journal for Nursing Sciences, 9(2), 1-7. https://www.iasj.net/iasj/article/174626

Riskesdas. (2018). Badan Penelitian dan Pengembangan Kesehatan. Jakarta: Departemen Kesehatan, Republik Indonesia

Sutrisna, M., Pranggono, E. H., \& Kurniawan, T. (2018). Pengaruh Teknik Pernapasan Buteyko terhadap ACT. Jurnal Keperawatan Silampari, 1(2), 47-61. https://doi.org/10.31539/jks.v1i2.22

Sutrisna, M., Arfianti, M. (2020). Pengaruh Teknik Pernapasan Buteyko terhadap Fungsi Paru Pada Pasien Asma Bronchial. Jurnal Kesehatan Saelmakers Perdana (JKSP), 3(1), 140-150. https://doi.org/10.32524/jksp.v3i1.240

Wijaya, I. K. A., Mertha, I. M., \& Rasdini, I. G. A. A. (2020). Teknik Pernapasan Buteyko dan Arus Puncak Ekspiras pada Pasien Asma. Jurnal Gema Keperawatan, 13(2), 111-119. https://ejournal.poltekkes-denpasar.ac.id/index.php/JGK/article/view/1320

World Health Organization (WHO). (2018). Asthma Fact Sheets. Diunduh dari https://www.who.int/news-room/fact-sheets/detail/asthma. Tanggal 25 Oktober 2021. Pukul 19.00

World Health Organization (WHO). (2021). Asthma Fact Sheets. Diunduh dari https://www.who.int/news-room/fact-sheets/detail/asthma. Tanggal 24 Oktober 2021. Pukul 16.00 